\title{
Rethinking Bildung in the Anthropocene: The Case of Wolfgang Klafki
}

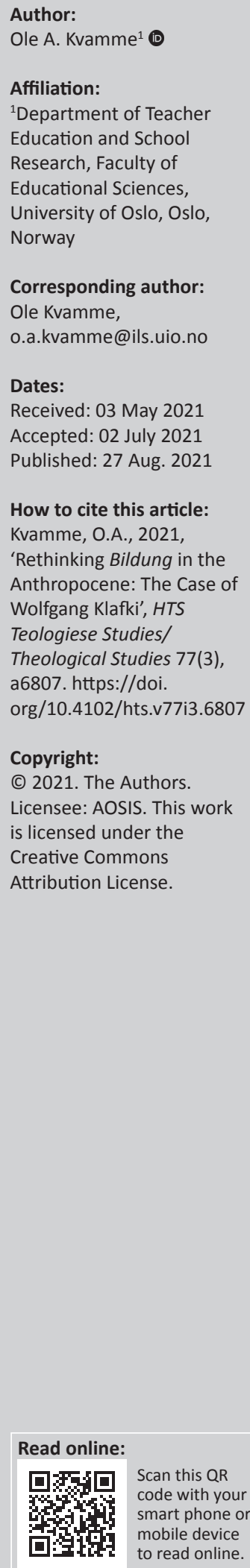

In this article, I discuss education in a time in the history when the human impact on Earth is massive and pervasive, with devastating consequences on the conditions for life. Within various academic fields, this era is increasingly distinguished as the Anthropocene. The term highlights the new, dominant position of the human species in Earth's history, but is contentious, hiding as much as it reveals. Humanity is surely not one, but many, participating in a complex web of relations constituted by other species and the material world. Moreover, the Anthropocene is also a time of global corporate capitalism, when the magnitude and the consequences of human activities are unequally distributed among humans and more-than humans alike. The ethical and political dimensions involved in this determine the reflections in this article. Specifically, I examine Wolfgang Klafki's educational theory as an expression of and a response to the Anthropocene. Klafki is a salient contributor to the rethinking of North European general didactics in the 20th century, in which Bildung, formations of the self, plays a key role. In Klafki's later works, epochal key problems are integrated in his concept of Bildung, addressing environmental crisis, social inequity, and threats to peace on Earth, in a global outlook that transcends Bildung's traditionally national scope. At the same time, Klafki's educational response expresses an anthropocentric outlook, which calls for rethinking. In such a rethinking I suggest to see the mediating element of the common, crucial in Klafki's Bildung theory, not as limited to human interests but as including concerns for life on Earth, and to conceive of historical situatedness as an aspect of the commonality of Bildung.

Contribution: The article explores how changing historical conditions in the present may have consequences for identity formation in schools and society. Education is conceived of as a field with strong ethical bearings. This article contributes to educational theory, reflecting on the conditions for Bildung in the Anthropocene.

Keywords: Bildung; the Anthropocene; globalisation; educational theory; general didactics; Klafki; environmental problems; critical theory; ideology critique.

\section{Introduction}

The current landscapes of identity are in vital ways marked by challenges emerging in the time of the Anthropocene. Central imaginaries associated with identity - human being, personhood, person, and the self - are, in fundamental ways, being shaken. The Anthropocene designates the present time interval as a new epoch of geological time dominated by human impact on Earth (Crutzen \& Stoermer 2000). The term refers to the processes of ongoing deterioration of the living conditions on Earth, caused by human activities, thereby threatening diverse life forms, including the human species itself. It has come into use even in social studies and the humanities. The term is also contentious (Gough 2021), concealing as much as disclosing power asymmetries. The human impact is expressed in structures and processes of unfair distribution of privileges and burdens, reflecting that responsibility for the current predicament is unequally distributed among the world's nations and the human population.

The ongoing changes associated with the Anthropocene have an impact on the research agenda of various fields, with numerous special issues appearing in well-established journals. A recent example is HTS Theological Studies' special collection addressing theology and nature (see the editorial by Buitendag [2020]) with 13 contributions, many of them examining theological discourses and religious practices, including multifaith contexts.

Note: Special Collection: New Landscapes in Identity: Theological, Ethical and Other Perspectives, sub-edited by John Klaasen (University of the Western Cape). 
In educational sciences, environmental education was established as a distinctive research field in the 1960s as a response to the emerging global environmental crisis (Hume \& Barry 2015), and it later became a part of UNESCO's global education policy $(1975,1977,2006,2014,2019,2020)$ following up on the United Nations' (UN) engagement with the environment and development (United Nations 1972, 1992a, 1992b, 1992c, 2002, 2012; United Nations General Assembly 2015, 2017). During these years, environmental and sustainability education has developed as a plural, multifaceted field. However, a prevailing challenge has been to integrate these perspectives in the dominant accounts of educational theory and school curricula (Gough 2018).

In this article, I address the challenges that education faces in the Anthropocene, by examining the late works of German curriculum theorist Wolfgang Klafki. I am, as a Norwegian scholar, situated in a North European context. Here Klafki is a central contributor to the renewal of educational theory during the 20th century (Künzli 2000), although the impact of learning oriented approaches has been considerable here, as elsewhere, during the last decades (Biesta 2009). In Klafki's later works published in the 1980s, under the influence of critical theory, he addressed the main societal and political challenges of his time, namely the global issues, such as environmental crisis, social and economic inequities, violence, and threats to peace. Klafki presented these concerns not as an explicit response to the UNESCO agenda or as contributions to the field of environmental education. They emerged from his reflections on the possible impact of current, societal challenges on Bildung, or formations of the self, a key concept in Klafki's account, as well as in North European educational theory since the early 19th century (Horlacher 2016). This makes the case of Klafki particularly interesting, for the reflections on educational challenges in our time of history.

Bildung is a concept with various meanings and connotations. However, according to Horlacher (2016) a persistent, common feature of it is:

[T] he supposition that there is a link between the individual and his or her (inner) cultivation [...] and the development of a better society brought about through the fulfillment of each individual that comprises it. (p. 2)

The normative vein and the mediation between the individual and society are of particular interest with regard to the concerns addressed in this article. In a reflection on Bildung and modernity Biesta makes the point that Bildung is an educational answer to a political question. If so, one must:

$[B]$ egin with a 'diagnosis' of our time. It is only on the basis of our answer to that question that we can return and ask what kind of educational response, what kind of Bildung might be needed or might make sense for us here and today - and what kind of Bildung might be possible. (Biesta 2002:346)

As I will discuss in the following sections, the diagnosis of our time is expressed by the concept of the Anthropocene, also complying with the view that a proper response to the Anthropocene requires a 'permanent capacity to rethink everything: institutions, practices, social structures, worldviews, principles, and systems' (Dryzek \& Pickerling 2019:12). Thus, as stated by the title, this article addresses the need to rethink the concept of Bildung in the Anthropocene.

Horlacher (2016) demonstrates how Bildung, which is rooted in the German-speaking world, is currently discussed in an international and intercultural context in a variety of ways. This is demonstrated by its relation to curriculum studies (in German: Didaktik, in the following mostly referred to as general didactics), as an alternative to the current emphasis on accountability. The subject of Bildung is considered as a means to address self-understanding and humanity, as an approach to school reform in the context of post-modern theories, and as a basis for action research.

Sjöström and Eilks refer to five educational traditions that may be directly related to Bildung theory. These are as follows: Classical Bildung emerging in a German tradition, Liberal Education conceived of as an Anglo-American version of Bildung, a Scandinavian Folk-Bildung emerging in the late 19th century, Democratic education as developed by Dewey, and critical-hermeneutic Bildung distinguished by Klafki's position. They consider Klafki's educational philosophy to represent 'the most complex and advanced concept of Bildung' (Sjöström \& Eilks 2020:58).

Academic interest in Klafki is ongoing. Scholars are discussing his works critically and constructively (eds. Köker \& Störtländer 2017; Strand 2002), rethinking him (eds. Braun, Stübig \& Stübig 2017), exploring the potential of his account to develop science education (Sjöström et al. 2017), and even employing his conception in reflections on information technology in education (Fuglseth 2018). Researchers bring Klafki's perspectives into the discussion of the knowledge question in curriculum studies (Willbergh 2016) and the status of critical thinking in education (Ryen 2019). Sjöström et al. (2017), inspired by Klafki, develop a conception of critical-reflexive Bildung, and they even address the issues of sustainability, pertinent to the issues addressed below. However, none of these works explicitly examine and discuss Klafki's account within the context of the Anthropocene.

In the following sections, I suggest that Klafki's later works may be conceived of as an early contribution to environmental and sustainability education (see also Kvamme 2020; Kvamme \& Sæther 2019), parallel to the establishment of the sustainability agenda. In one respect, Klafki anticipates later developments within pedagogy and educational theory. In another, a closer, critical examination of Klafki's account also demonstrates the persistence of hegemonic structures involved in transforming the educational theory and practices in the Anthropocene. In a recent study of education in the Anthropocene, Australian Gough (2021:n.p.) points at how there are still silences around connecting with nonhuman nature and the more-than-human'. South African scholar Heila Lotz-Sisitka makes a similar observation, when she - addressing the UNESCO document Rethinking Education: Towards a Global Common Good? (UNESCO 
2015) - comments on the lack of concern for 'the more-thanhuman', which should be considered (Lotz-Sisitka 2017:68). Such silences and absences also distinguish Klafki's account, as I demonstrate below.

Conceived of in this way, my contribution here is mainly theoretical, rethinking Bildung theory in the Anthropocene. However, Klafki's account, and particularly his monography on Bildung theory and didaktik (Klafki 1996) (originally published in 1985, here referred to in the 1996 edition) may also be seen as empirical material that is examined with a critical hermeneutical approach (Ricoeur 1981; see also Kvamme 2020). (The author is responsible for the English translations of quotations from the German version.) In that perspective, this article is an instance of qualitative research that demonstrates deliberations of educational theory in the Anthropocene. Løvlie and Standish (2002:335) state in a reflection on the conditions for Bildung in postmodern societies that 'whatever Bildung is today, it cannot pretend to have universal validity'. Neither is such a claim made in the following. In this article, Klafki is employed as a vital and influential, but, nevertheless, specific example and case. Still, I expect that the perspectives and considerations that are presented below, may prompt further reflections within various contexts on education in the Anthropocene and current challenges that indeed are global in scope.

\section{The Anthropocene}

The concept of the Anthropocene was introduced by Paul Crutzen and his colleague Eugene F. Stoermer more than 20 years ago (Crutzen \& Stoermer 2000), as an epochal term designating the massive, transformative human influence on Earth. Crutzen and Stoermer suggest that the concept of the Anthropocene should be included in the geological time scale as the epoch following the Holocene that started in the aftermath of the last glacial stage almost 12000 years ago. Among geological scientists, the question of the definition concerns whether the Anthropocene is a new interval in geological history determined by stratigraphic evidence. The Anthropocene Working Group submitted a formal proposal for the term to the International Commission on Stratigraphy in 2019 (Gough 2021). However, Hamilton, Bonneuil and Gemenne (eds. 2015) mention two other definitions that indicate how the Anthropocene has been appropriated, adopted, and explored within a range of academic disciplines. A second definition comes from Earth system science and it is not limited to strictly stratigraphic evidence. The Stockholm Resilience Centre's work on 'planetary boundaries' identifying nine different systems on Earth that accommodate safe living conditions, among them the climate system - falls under this approach (Rockström et al. 2009). A third definition of the Anthropocene further extends the scope of meaning, by explaining how human impact on the Earth has resulted in urbanisation, species extinction, resource extraction, and waste dumping. Scientific reports are regularly published that point to the gravity of this situation, both in terms of present harm to life on Earth and probable future harm. The scientific panels on Climate Change (IPCC) and biodiversity and Ecosystem
Services (IPBES), appointed by the UN, continuously publishes their results (IPBES 2019; IPCC 2018) related with these issues. They are closely related to the Framework Convention on Climate Change and the Convention on Biodiversity, both of which the UN (1992b, 1992c) has adopted.

The concept of the Anthropocene is widely used. But, as mentioned in the introduction, the term is still contentious, because of its humanist and human supremacy focus neglecting the intimate relationships between technology, humans, and the more-than-human, and because of the way it hides differences between humans, including the distribution of privileges and burdens (Gough 2021). In a recent article on education in the Anthropocene, Gough (2021) acknowledges the critique, but still uses the term 'for its capacity to do useful work as the term has been taken up within the humanities and by artists, social scientists and scientists' (Gough 2021:n.p.). In the following, I align with this position. However, the objections referred to above, warrants a consideration of the historical situatedness of the Anthropocene. A key issue, then, is not only to understand the consequences of the Anthropocene but also to address the conditions and even the causes leading up to the present ecological crisis.

\section{Globalisation and modernity}

The Anthropocene is closely linked to industrialisation, economic growth, and globalisation.

Crutzen and Stoermer (2000:17) suggest the industrial revolution as the starting point of it. In the present, scholarly opinion converges on 1945 (eds. Hamilton et al. 2015:1), coinciding with the onset of the 'Great Acceleration', a designation of the decades after World War II distinguished by strong economic growth. It was initially limited to Western industrial countries, but later spreading to other parts of the world. More than three-quarters of the total emissions of carbon dioxide took place after World War II, and since this period, the world's population has more than tripled (McNeill \& Engelke 2014). The greatest increase in production and consumption began after 1980. In this period, economic globalisation gained speed, and international treaty agreements were signed to allow the free transportation of capital, commodities, and services across national borders. At the same time, the problems such as resource depletion, deforestation, species extinction, pollution, and greenhouse gas emissions have been accelerated, substantiating a relationship between economic globalisation and ecological crisis.

With the indisputable hegemony of corporate global capitalism followed by the opening of a free-market economy in China in the 1970s and in the Soviet Union in the 1980s, the relation between capitalism and the present ecological crisis may easily be recognised. Environmental historian Moore (2015), contributing to the critique of the Anthropocene, prefers the term the Capitalocene, to demonstrate the substantial, ubiquitous, and devastating influence of the 
capitalist economy. He argues that this historical period began already in the 15th century.

Political theorists Christoff and Eckersley (2013:10) acknowledge the relationship between corporate global capitalism in its neoliberal form and the ecological crisis, but claim that the historical rise of instrumental rationality, new scientific inquiry, and changes in the human relationship with the larger non-human world constitute the seminal background for the current crisis. Christoff and Eckersley's (2013) conception is strongly connected to the meta-narrative of prosperity and progress characterising modernity (Von Wright 1997).

Moore's and Christoff and Eckersley's approaches demonstrate how an analysis of the massive human impact on the Earth involves ethical and political considerations. This perspective guides my reference to the Anthropocene in the following with regard to education and Bildung.

I have discussed the priority given to the educational theory of Wolfgang Klafki in the beginning of this article. With regard to the issue of identity, it is also good reason to emphasise that situating the concept of Bildung in the Anthropocene certainly demonstrates how the current crises have an impact on formations of the self.

\section{Wolfgang Klafki's educational theory}

In German educational theory, the purpose of education has a major role, with a determining function in the content issue (Klafki 1996; Künzli 2000; Westbury 2000). Bildung is the decisive expression of educational purpose, emphasising the emancipation of students from heteronomy to autonomy, that is, from being determined by the influence of others to self-determining. This personal development, embedded in the philosophical tradition of modernity going back to Kant, takes place in social practices in which cultural expressions play a major role constituting the educational content. In that respect, Bildung also involves processes of socialisation and edification. Bildung may take place everywhere. However, within the educational tradition Klafki adheres to, it is framed by national educational systems in which processes of Bildung also have been linked to the construction of national identity and imaginaries of the nation-states (Masschelein \& Ricken 2010).

In Klafki's first contributions from the late 1950s, and chiefly in his doctoral thesis (defended in 1959; Klafki 1964), he identified and discussed various historical forms of Bildung and elucidated how the topic could be dealt with in societies distinguished by an overload of information. He concluded by introducing categorical Bildung as a key concept in a new educational account, signifying how the educational content should exemplify fundamental categories in ways that opened the student to the world.

Klafki's reconsiderations in the 1980s and 1990s of his educational theory form the basis for my analysis of his contributions. Although Klafki builds on the overall theoretical framing of previous works, several changes have taken place that reflect an educational theory forged in the globalised world of the Anthropocene. In the first part of the analysis, I point out aspects of Klafki's account that demonstrate how he rethinks his educational theory in response to the historical changes that have been taking place. In the second part, I identify elements that may be seen as expressions of human exceptionality in the Anthropocene. In the final part, prompted by this analysis, I reflect on how Klafki's account may be further developed, with particular reference to how the manifold web of life is now under threat.

\section{To comply with historical changes}

A conspicuous dimension of Wolfgang Klafki's academic life is a willingness to practise an ongoing rethinking of numerous elements of his educational theory. This justifies the priority I give to his contributions in the following section.

\section{A global scope}

A significant aspect of Klafki's account concerns the educational scope, considering the reach of the perspectives brought forward. As discussed above, the nation-state has been considered to frame educational practices in the tradition of general didactics. In the 1980s, the scope of Klafki's educational theory is no longer determined by national borders, limited to the nation-state as a self-sufficient entity. Klafki acknowledges that ambiguous globalisation processes are taking place in the present, including the interweaving of continents, cultures, nation-states, and cultures around the world. Although these processes are distinguished by conflicts and asymmetries of power and wealth, Klafki does not envisage that the interweaving processes of globalisation will end. Instead, they condition the current state of affairs. In this situation, the call to pedagogy is to:

$[D]$ evelop a universal horizon, that in principle includes all nation states and cultures. However, from such a global perspective the following considerations should be made: What insights, abilities and attitudes do young people need in the future, enabling them to productively deal with universal developments and problems and gradually be able to exercise judgment, co-determination and action? (Klafki 1996:80)

This global scope also distinguishes Klafki's rethinking of the Bildung ideal. He stresses the commonality of Bildung - it is not restricted to a certain societal class, as was the case in German educational history, or to particular societies, but accrues to all, everywhere. With Klafki's hermeneutical position in mind (Klafki 1996:98-114), this concern should not be seen as the universalisation of a particular educational system, but indicates that the privileges of Bildung are not limited and restricted to certain groups.

\section{Rethinking the canon problem: Epochal key problems}

As a consequence of the global outlook, Klafki reconsiders the so-called canon problem of education. He refers to how 
for a long time the content issue has been conceived of as a question of selecting mandatory cultural elements that historically have received the status of classical achievements within science, arts, ethical reflection, and life. Faced with challenges and conflicts in the current society, Klafki now claims that educational content should be largely constituted by 'the key problems, that globally interweave our individual and political-societal existence' (Klafki 1996:154). Therefore, education turns out not to be a question of transmitting certain representations of knowledge but of initiating students in unresolved societal challenges that determine their future. Education entails ethical and political concerns, and based on this viewpoint, Bildung is tantamount to:

[G]ain a historically mediated awareness of key problems in current society and - as far as it is predictable - in the future, the insight that everyone is co-responsible for such problems, and a readiness to contribute to the mastery of the problems. (Klafki 1996:56)

Klafki (1996:60) concludes that the key problems, all conceived of as historically situated, should not be presented as an ultimate list but continuously be subjected to amendment. However, he envisages that they become part of the curriculum and suggests five themes to include: the peace issue, environmental problems, societal inequity within and across nation-states, the hazards and possibilities of information and communication technology, and experiences with love and sexuality.

\section{Ideology critique}

As we have seen above, Klafki extends the educational scope beyond the nation-state, and in his reformulation of the canon problem, he includes environmental issues and social inequity. In this rethinking, he integrates insights from critical theory, with Habermas as a major influence, addressing how hegemonic structures and practices may suppress and limit the conditions for self-determination. This reflexive approach involves students, teachers, and teacher educators with implications for education in school, teacher training, and research that is carried out. The critical emphasis also determines Klafki's designation of his approach as a critical-constructive didaktik (Klafki 1996:139-161, 1998).

The critical perspective draws attention to hegemonic imaginaries that are continuously reproduced in school and education. Klafki follows critical theory's conception of ideology as a mistaken societal consciousness (Klafki 1996:111). Ideology legitimises current relations of power and dependence, conceived of as natural and given.

Thus far, I have demonstrated how Klafki's renewal of the North European general didactics reflects the historical changes taking place in the Anthropocene. Most striking is the positioning of environmental problems in the new canon. However, the extension of the educational scope from the nation-state to the global stage is even more wide-ranging. When it comes to the potential of an educational theory for renewal and transformation, the critical perspective that is included seems to be crucial.

\section{Extending human dominance}

In the following section, I examine how Klafki's conceptions in themselves may be said to carry on the human dominance that defines the Anthropocene as a historical period. In this phase of the analysis, then, I focus on the limitations that in the third and final part of the article prompt further rethinking.

\section{What are the environmental problems?}

Klafki addresses environmental problems as a question of 'the deterioration or preservation of the natural basis for human existence' (Klafki 1996:58). Consequently, he calls for education that addresses over-consumption of natural resources. He points out possible solutions to the problems, including the reduction of consumption, technological innovation, and the achievement of democratic control of economic-technological development.

This account is unreservedly anthropocentric, considering nature as a resource for human existence. Environmental problems are considered as threats, because they jeopardise the living conditions for the human species. Klafki's attention does not remain on the threats in themselves, but moves directly to problem solving. The envisaged student is able to manage, deal with, and solve the problems. This complies well with the overall purpose of Bildung, according to Klafki, including not just self-determination but also codetermination and solidarity (Klafki 1996:52). The selfdetermined human being shall take responsibility for the society, by contributing to the transformation of structures that prevent others from achieving self-determination and co-determination. (A similar observation concerning Klafki's Bildung ideal, is made by the philosopher of education Torill Strand [2002]).

This conception emphasises the human attributes of control and agency, monitoring natural resources for the benefit of the human species. In Klafki's account, there are considerations of limits on growth, further emphasising the need for responsible housekeeping of natural resources. However, Klafki never refers to nature as a diverse, manifold, flourishing world of species, which is beyond the scope of his concern.

\section{Ethical foundations}

The tradition of general didactics, including Klafki, is distinguished by a sensitivity and an awareness of the normativity involved in educational practices, accentuating that the purpose of Bildung is related to all educational practices. Therefore, pedagogical concerns stand out as ethical considerations, as well. A prominent example of this connectedness emerges in a discussion of how proposals for solving the epochal key problems should be determined. 
Klafki introduces the following premise: 'To what extent is it possible to generalize the principles, that ground a proposal, in ways that accrues to everybody involved' (Klafki 1996:61). He is referring to the position of discourse ethics, as developed by the German philosophers Jürgen Habermas and Karl-Otto Apel. In a contribution to a Festschrift dedicated to Wilhelm Flitner (Klafki 1989), Klafki elaborates on this problem, accentuating the normativity involved in educational practices, explicitly grounding the issue of purpose in a discourse ethical approach. Klafki calls for an educational science that employs practical discourses when exploring the possibility to reach consensus on pedagogical purpose (Klafki 1989:157).

Discourse ethics aims at establishing ethical principles as a foundation for action, an orientation approved by Klafki. This approach stands in the deontological tradition of Immanuel Kant, emphasising how the practising of moral judgement should take place detached from contextual factors and a narrow self-interest. As established by Jürgen Habermas, discourse ethics is anthropocentric oriented toward the needs of the present. In this respect, discourse ethics confirms modernity's denial of nature, as Norwegian philosopher Vetlesen (2015) puts it in his critique of this anthropocentric dimension of Habermas' account. Regarding Klafki's account, the lack of attention to the integrity of a more-than-human world with its own interests is confirmed in the ethical grounding of his educational theory.

\section{The content problem}

As demonstrated above, Klafki grounds the issue of educational purpose in a discourse ethical approach, without an awareness of the integrity of the more-than-human world. This approach has consequences for the conceptualisation of other vital categories in his educational theory. Within the tradition of general didactics, a decisive issue is the content problem, that is, about what educational content should be selected, encouraging students' Bildung. In his more detailed elaboration, Klafki (1996:118) distinguishes between 'content' and 'theme'. Content designates something outside the classroom that has potential to be brought into educational practices. Theme designates aspects of the content that are pertinent to the educational context. The formulation of theme is determined by the educational purpose, in its most general form the Bildung of self-determination, co-determination, and solidarity. One of Klafki's examples is 'India', a content that he suggests may become a theme conceived of as an example of nutrition and population problems in a developing country.

In this structure, the function of educational purpose is decisive, warranting the selection of content that may become a theme. However, Klafki makes a reservation regarding an instrumental conception of purpose, connected with deduction (Klafki 1996:117). Purpose should not unequivocally be conceived of as external to the hermeneutical process involved in the establishment of educational themes, but is to be found within the process itself. Nevertheless, the structure that I disclosed above demonstrates how the anthropocentric outlook distinguishing Klafki's conception is restated in the didactical structure. In a more general vein, this analysis demonstrates a point made by Klafki himself (1996:112-113), how hegemonic imaginaries are rearticulated in educational practices. In Bernstein's (2000) conceptualisation, the content outside the educational context is recontextualised as themes, and in this process, ideology is at work.

\section{Further rethinking of Bildung}

There are obvious qualities that should be emphasised in Klafki's conception as identified in the analysis above. Most important is his acknowledgment of educational theory as closely linked to societal concerns and issues. The emphasis on fundamental ethical concerns is also pivotal in times when learning often is studied without consideration to educational purpose (Biesta 2009). Strongly connected to this is Klafki's critique of any parochial tendency, limiting education to particular groups or narrow national interests, opening up for universal perspectives, global responsibility, and global justice. Vital for an educational theory reflecting challenges in the Anthropocene is also his rearticulation of the canon problem addressing epochal key problems.

However, we have also seen how the human being within Klafki's educational theory is positioned as a species entitled to a solely instrumental relationship with the complex and manifold webs of life that constitute the biosphere of Earth. I claim that this imaginary is inadequate for an updated educational theory in the Anthropocene, because it maintains the very structure that conceals the interests of other species. The transformations called for in the current situation include a rethinking of this structure, involving questions of identity. In the concluding part of this article, I address some key elements in Klafki's account, which call for rethinking, well aware of how Klafki himself throughout his life demonstrated that an educational theory as historically situated should be open continuously to changes and further development.

\section{Identifying 'the mediating element of the common'}

When Klafki presents the educational priority of epochal key problems, he refers to 'the mediating element of the common' as a decisive aspect of Bildung (Klafki 1996:53). This formulation expresses an interest articulated throughout his account; to steer clear from a narrow, subjective conception of self-determination, constituting the classical purpose within Bildung theory. In another formulation, Klafki (1996) states:

In a consideration of the common in Bildung as pedagogical binding today, I hold that what concerns us and the envisioned, coming generations most, has to be put at centre stage: The societal and individualistic key problems of existence. (p. 29)

Klafki leans on the philosopher Michael Theunissen (1982), who claims that 'self-realization in the present should include the concern for the global exploitation of the nature, the consternation of hunger throughout the world, and the care for peace on earth' (p. 46). In his own account, Klafki refers to Theunissen's call to pursue these particular issues - in 
brackets stating 'i.e. tasks, W. $\mathrm{Kl}^{\prime}$. However, the distinction between issue and task appears to be significant, demonstrating a limitation in Klafki's account. Theunissen's discourse is distinguished by words like consternation and care. A consistent element in Klafki's theory is the conception of a human being furnished with agency, expressed in words like tasks, principles, norms (cf. the references to discourse ethics), and solutions (cf. the approach to environmental problems, referred to above). Significant is also that the key problems are formulated exactly as problems, and not as concerns.

In his articulation of key problems Klafki is premising human beings who are able to solve them. As crucial as solutions to the main problems in the Anthropocene may be, I still suggest that Klafki skips a crucial step here. If the key problems are formulated instead as concerns for life on Earth now and in the future, then the threats to human and more-than-human life become visible in the Anthropocene because of human exploitation of nature. In that perspective, the vulnerability of the human species, in spite of human agency, is not qualitatively different from that of other species. This is an invitation to explore parallels and similarities between the human and more-than-human species, before moving to the step of human agency. Moreover, relationships and interdependencies that are orchestrating themselves in the Anthropocene may become visible.

In this rethinking of Klafki, the mediating element of the common, crucial in Bildung theory, is not limited to human interests, but concerns life on Earth. In that case, processes of self-determination and self-realisation may be conceived of as engaging in protecting life on Earth in all its diversity, opening up conceptions of human identity that include human relationships with other species.

\section{Historical situatedness as an aspect of commonality}

In the discussion above, I demonstrate an aspect of Klafki's theory that deserves attention, that is, the relationship between historical situatedness and general or universal knowledge. On one hand, Klafki's educational theory is deeply embedded in a hermeneutical perspective that acknowledges that any cultural expression is always particular, and historically situated. On the other hand, his Bildung theory continuously focuses on the generality of any theme designed for educational practices. The emphasis on generality even accrues to his reference to discourse ethics, as we have seen, grounding educational purpose. His main reference is Habermas who envisages that the deliberations of discourse ethics are framed at a distance from specific contexts. This element is subject to Benhabib's (1992) critique in her rethinking of Habermas's account, a perspective that may also have bearings on Klafki's adoption of Habermas. Informed by feminist theory, Benhabib criticizes abstract versions of moral theory that do not consider the situatedness of those who are affected by a particular action. She points at how the needs of the other are hardly visible if the other is generalized with an unambiguous emphasis on abstract characteristics like freedom, rationality, and independence. Then, she emphasises the significance of the concretized other embedded in a world of interdependency and the conception of moral judgment as an everyday activity:

The exercise of moral judgment is pervasive and unavoidable: in fact, this exercise is coextensive with relations of social interaction in the lifeworld in general. Moral judgment is what we 'always already' exercise in virtue of being immersed in a network of human relationships that constitute our life together. (Benhabib 1992:128)

The main challenge is how the significant network of 'relationships that constitute our life together' may be taken care of in an educational theory, when content is reframed in educational themes, as we have seen is the case in Klafki's account. The risk is that the qualities distinguishing the situatedness of particular contexts may be lost, when the generality of categorical Bildung is accentuated. Klafki is aware of the importance of accommodating the experiences of students ('the fundamental'), but then expresses a distinction with the objective side, emphasising the generality ('the elementary'). In a rethinking of this crucial aspect of Klafki's educational theory, I suggest that the historical situatedness of students, in itself particular, is recognised as a common condition, designating all life on Earth, shared by human beings and the more-than-human world alike. This interpretation of the generality of particularity may bring historical situatedness into the centre of educational theory.

\section{Concluding remarks}

In the final part of his career, Wolfgang Klafki developed his educational theory into a critical-constructive general didactics (Klafki 1996, 1998). At this point, the common character of the educational aim of Bildung accommodated ideology critique with a global outlook and the extension of the content issue to include epochal key problems. In this article, this educational account has been subjected to scrutiny. I have suggested that these elements are all pertinent responses to the challenges emerging in the Anthropocene, including environmental problems, social inequity and global injustice. Klafki demonstrates the potential of Bildung to accommodate a global perspective and represent a transformative perspective on school and education that includes both ethical and political dimensions.

In her reflections on education in the Anthropocene, it is exactly a critical, reconstructive education, Annette Gough (2021), referred to in the introduction, calls for. But Gough's elaborations also offer perspectives on limitations characterising Klafki's account. Assessing the field of environmental education, Gough points at a lack of considerations on the significance of human connections with other species and the more-than-human world and the need to embrace and engage ecological and human vulnerability. These absences also characterise Klafki's conceptions as discussed in this article. 
The limitations of Klafki's account with regard to Bildung in the Anthropocene, are, as I have put forward here, primarily connected with a consistent anthropocentric outlook. In his Bildung theory, Klafki envisages human beings with agency and abilities to problem solving, but he does not dwell on how human life is embedded in the larger web of life, involving connections, dependencies and vulnerabilities. In a rethinking of Klafki, I have primarily pointed at the potential of conceiving 'the mediating element of the common' as not limited to human interests, but encompassing concerns for life on Earth, and to see historical situatedness as an aspect of commonality. With reference to Benhabib's emphasis on the webs of life that we are always already a part of, a central issue for Bildung in the Anthropocene should be how the network of relationships that constitute life may be taken care of in an educational theory that accommodates both intragenerational and intergenerational justice and ecojustice.

\section{Acknowledgements}

The author acknowledges helpful suggestions from Karin Sporre as the co-editor of this special collection.

\section{Competing interests}

The author declares that he has no financial or personal relationships that may have inappropriately influenced him in writing this article.

\section{Author's contributions}

O.A.K. is the sole author of this research article.

\section{Ethical considerations}

This article followed all ethical standards for research without direct contact with human or animal subjects.

\section{Funding information}

This research received no specific grant from any funding agency in the public, commercial or not-for-profit sectors.

\section{Data availability}

Data sharing is not applicable to this article as no new data were created or analysed in this study.

\section{Disclaimer}

The views and opinions expressed in this article are those of the author and do not necessarily reflect the official policy or position of any affiliated agency of the author.

\section{References}

Benhabib, S., 1992, Situating the self, Polity Press, Cambridge.

Bernstein, B., 2000, Pedagogy, symbolic control and identity: Theory, research, critique, rev. edn., Rowman \& Littlefield Publishers, Lanham, MD.
Biesta, G., 2002, 'Bildung and modernity: The future of Bildung in a world of difference', Studies in Philosophy and Education 21, 343-351. https://doi. org/10.1023/A:1019874106870

Biesta, G., 2009, 'Good education in an age of measurement: On the need to reconnect with the question of purpose in education', Educational Assessment, Evaluation and Accountability, formerly: Journal of Personnel Evaluation in Education 21(1), 33-46. https://doi.org/10.1007/s11092-008-9064-9

Braun, K.-H., Stubig, F. \& Stubig, H. (eds.), 2017, Erziehungswissenschaftliche Reflexion und Padagogisch-Politisches Engagement. Wolfgang Klafki Weiterdenken, Springer, Dordrecht.

Buitendag, J., 2020, 'Grandeur in this view of life', HTS Teologiese Studies/Theological Studies 76(1), a6351. https://doi.org/10.4102/hts.v76i1.6351

Christoff, P. \& Eckersley, R., 2013, Globalization and the environment, Rowman \& Littlefield Publishers, Lanham, MD.

Crutzen, P.J. \& Stoermer, E.F., 2000, 'The Anthropocene: An epoch of our making', Global Change Newsletter 41, 17-18.

Dryzek, J. \& Pickering, J., 2019, The politics of the Anthropocene, Oxford University Press, Oxford.

Fuglseth, K. (ed.), 2018, Kategorial danning og bruk av IKT i undervisning [Categorical Bildung and the use of ICT in education], Universitetsforlaget, Bergen. https://doi. org/10.18261/9788215029450201802

Gough, A., 2018, 'Sustainable development and global citizenship education: Challenging imperatives', in I. Davies, L.C. Ho, D. Kiwan, C.L. Peck, A. Peterson, E. Sant et al. (eds.), The Palgrave handbook of global and education, pp. 295-312, Palgrave Macmillan, London. https://doi.org/10.1057/978-1-137-59733-5_19

Gough, A., 2021, 'Education in the Anthropocene', in C. Mayo (ed.), Oxford encyclopedia of gender and sexuality in education, n.p., Oxford University Press, New York, NY. https://doi.org/10.1093/acrefore/9780190264093.013.1391

Hamilton, C., Bonneuil, C. \& Gemenne, F. (eds.), 2015, The Anthropocene and the global environmental crisis. Rethinking modernity in a new epoch, Routledge, New York, NY.

Horlacher, R., 2016, The educated subject and the German concept of Bildung - A comparative cultural history, Routledge, London.

Hume, T. \& Barry, J., 2015, 'Environmental education and education for sustainable development', in N.J. Smelser \& P.B. Baltes (eds.), International encyclopedia of the social \& behavioral sciences, pp. 733-739, Elsevier, Amsterdam.

IPBES (Intergovernmental Science-Policy Platform on Biodiversity and Ecosystem Services), 2019, Summary for policymakers of the global assessment report on biodiversity and ecosystem services, viewed 15 March 2021, from https://www. ipbes.net/sites/default/files/downloads/spm_unedited_advance_for_posting htn.pdf.

IPCC (Intergovernmental Panel on Climate Change), 2018, Global warming of 1.5ㅇ. Special report, viewed 15 March 2021, from https://www.ipcc.ch/sr15/.

Klafki, W., 1964, Das pädagogische Problem des Elementaren und die Theori der kategorialen Bildung [extended version of the thesis from 1959], J. Beltz, Weinheim.

Klafki, W., 1989, 'Kann Erziehungswissenschaft zur Begründung pädagogischer Zielsetzungen beitragen? - Über die Notwendigkeit bei pädagogischen Entscheidungsffragen hermeneutische, empirische und ideologiekritische .). Richtungs \& H. Scheulerl (eds.), Richtungsstreit in der Erziehungswissenschaft und pädogische Verständigung. Wilhelm Filtner zur Vollendung seines 100. Lebensjahres am 20. August 1989 gewidmet, pp. 147-159, Verlag Peter Lang, Frankfurt am Main.

Klafki, W., 1996, Neue Studien zur Bildungstheorie und Didaktik. ZeitgemäBe AllgemeinBildung und kritisch-konstruktive Didaktik, Beltz Verlag, Weinheim.

Klafki, W., 1998, 'Characteristics of critical-constructive Didaktik', in B. Gundem \& S. Hopmann (eds.), Didaktik and/or curriculum. An international dialogue, pp. 307-328, Peter Lang, New York, NY.

Köker, A. \& Störtländer, J.C. (eds.), 2017, Kritische und konstruktive Anschlüsse an das Werk Wolfgang Klafkis, Weinheim, Beltz Juventa.

Künzli, R., 2000, 'German Didaktik: Models of re-presentation, of intercourse, and of experience', in I. Westbury, S. Hopmann \& K. Riquarts (eds.), Teaching as a reflective practice. The German Didaktik tradition, pp. 41-54, Routledge, New York, NY.

Kvamme, O., 2020, 'Recontextualizing environmental ethical values in a globalized world: Studies in moral education', PhD thesis, Faculty of Educational Sciences, University of Oslo, viewed 15 March 2021, from http://hdl.handle.net/10852/75162.

Kvamme, O. \& Sæther, E., 2019, 'Bærekraftdidaktikk - spenninger og sammenhenger' [Sustainability Didaktik - Tensions and connections], in O. Kvamme \& E. Sæther (eds.), Bærekraftdidaktikk [Sustainability Didaktics], pp. 16-40, Fagbokforlaget, (eds.), Bare
Bergen.

Lotz-Sisitka, H., 2017, 'Education and the common good', in B. Jickling \& S. Sterling (eds.), Post-sustainability: Remaking education, pp. 63-78, Palgrave MacMillan, Basingstoke.

Løvlie, L. \& Standish, P., 2002, 'Introduction: Bildung and the idea of a liberal education', Journal of Philosophy of Education 36(3), 317-340. https://doi. org/10.1111/1467-9752.00279

Masschelein, J.S. \& Ricken, N., 2010, 'Bildung', in P. Peterson, R. Tierney, E. Baker \& B. McGaw (eds.), International encyclopedia of education, pp. 127-132, Elsevie Science, Amsterdam. https://doi.org/10.1016/B978-0-08-044894-7.01301-4

McNeill, J.R. \& Engelke, P., 2014, The great acceleration: An environmental history of the Anthropocene since 1945, The Belknap Press of Harvard University Press, Cambridge, MA.

Moore, J., 2015, Capitalism in the web of life: Ecology and the accumulation of capital, Verso, London. 
Ricoeur, P., 1981, Hermeneutics and the human sciences, Cambridge University Press, Cambridge.

Rockström, J., Steffen, W., Noone, K., Persson, Å., Chapin, F.S., Lambin, E. et al., 2009, 'Planetary boundaries: Exploring the safe operating space for humanity', Ecology and Society 14(2), 32.

Ryen, E., 2019, 'Klafki's critical-constructive Didaktik and the epistemology of critical thinking', Journal of Curriculum Studies 52(2), 214-229. https://doi.org/10.1080/ 00220272.2019 .1657959

Sjöström, J. \& Eilks, l., 2020, 'The Bildung Theory - From von Humboldt to Klafki and Beyond', in B. Akpan \& T. Kennedy (eds.), Science education in theory and practice, Springer Texts in Education, Springer, Cham. https://doi.org/10.1007/978-3-03043620-9_5

Sjöström, J., Frerichs, N., Zuin, V.G. \& Eilks, I., 2017, 'Use of the concept of Bildung in the international science education literature, its potential, and implications for teaching and learning', Studies in Science Education 53(2), 165-192. https://doi.or $\mathrm{g} / 10.1080 / 03057267.2017 .1384649$

Strand, T., 2002, 'Kan pedagogikken bygge et mer humant samfunn? Et kritisk blikk på Wolfgang Klafkis didaktik' [Is pedagogy capable of building a more human society? A critical perspective on Wolfgang Klafki's general didactics], Norsk pedagogisk tidsskift 86(2-3), 124-142. https://doi.org/10.18261/ISSN1504-2987-2002-02 03-05

Theunissen, M., 1982, Selbstverwirklichun und Allgemeinheit: zur Kritik des gegenwärtigen Bewusstseins, Walter de Gruyter, Berlin.

UNESCO, 1975, The Belgrade Charter: A framework for environmental education, viewed 15 March 2021, from https://unesdoc.unesco.org/ark:/48223/pf0000017772.

UNESCO, 1977, The Tbilisi declaration, viewed 15 March 2021, from https://unesdoc. unesco.org/ark:/48223/pf0000028431?posInSet=2\&queryld=c92f127c-0fa4 4bd7-aa81-13efa209409b.

UNESCO, 2006, Framework for the DESD draft implementation scheme, viewed 15 March 2021, from https://unesdoc.unesco.org/ark:/48223/pf0000148650.

UNESCO, 2014, UNESCO roadmap for implementing the global action programme on education for sustainable development, viewed 15 March 2021, from https:// sustainabledevelopment.un.org/content/documents/1674unescoroadmap.pdf.

UNESCO, 2015, Rethinking education: Towards a global common good?, viewed 15 March 2021, from https://unevoc.unesco.org/e-forum/RethinkingEducation.pdf.

UNESCO, 2019, Education for sustainable development: Towards achieving the SDGs (ESD for 2030). A draft framework for the implementation of Education for Sustainable Development beyond 2019, viewed 15 March 2021, from https:// Sustainable Development beyond 2019, viewed 15 March
unesdoc.unesco.org/ark:/48223/pf0000370215.locale=en.
UNESCO, 2020, Education for sustainable development. A Roadmap. ESD for 2030, viewed 15 March 2021, from https://unesdoc.unesco.org/ark:/48223/ pf0000374802.

United Nations, 1972, Report of the United Nations conference on the human environment, Stockholm, 5-16 June 1972, viewed 15 March 2021, from http:// www.un-documents.net/aconf48-14r1.pdf.

United Nations, 1992a, Agenda 21, viewed 15 March 2021, from https:// sustainabledevelopment.un.org/content/documents/Agenda21.pdf.

United Nations, 1992b, United Nations framework convention on climate change, viewed 15 March 2021, from https://unfccc.int/resource/docs/convkp/ conveng.pdf.

United Nations, 1992c, The convention on biological diversity, viewed 15 March 2021 from https://www.cbd.int/convention/text/default.shtml.

United Nations, 2002, Report of the world summit on sustainable development, Johannesburg, 26 August - 4 September 2002, viewed 15 March 2021, from https://undocs.org/en/A/CONF.199/20.

United Nations, 2012, Resolution 66/288. The Future we want, adopted by the General Assembly on 27 July 2012, viewed 15 March 2021, from https://www. un.org/ga/search/view_doc.asp?symbol=A/RES/66/288\&Lang=E.

United Nations General Assembly, 2015, Resolution 70/1. Transforming our world: The 2030 agenda for sustainable development, viewed 15 March 2021, from https:// www.un.org/en/development/desa/population/migration/generalassembly/ docs/globalcompact/A_RES_70_1_E.pdf.

United Nations General Assembly, 2017, Resolution 72/222. Education for sustainable development in the framework of the 2030 agenda for sustainable development Resolution adopted by the General Assembly on 20 December, viewed 15 March 2021, from https://www.un.org/en/ga/72/resolutions.shtml.

Vetlesen, A.J., 2015, The denial of nature. Environmental philosophy in the era of global capitalism, Routledge, London.

Von Wright, G.H., 1997, 'Progress: Fact and fiction', in A. Burgen, P. McLaughhlin \& J. Mittelstrab (eds.), The idea of progress, pp. 1-18, Walter de Gruyter, Berlin.

Westbury, I., 2000, 'Teaching as a reflective practice: What might Didaktik teach curriculum?', in I. Westbury, S. Hopmann \& K. Riquarts (eds.), Teaching as a reflective practice. The German Didaktik tradition, pp. 15-39, Routledge, New York, NY.

Willbergh, I., 2016, 'Bringing teaching back in: The Norwegian NOU The school of the future in light of the Allgemeine Didaktik theory of Wolfgang Klafki', Nordisk Tidsskrift Pedagogikk \& Kritikk 2(3), 111-124. https://doi.org/10.17585/ntpk. v2.268 